Boletín de la Sociedad Geológica Mexicana

VOLUMEN 61, NÚM. 1, 2009, P. 73-86

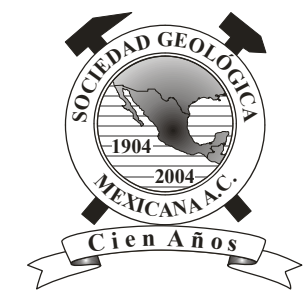

\title{
Distribution of total organic carbon and total nitrogen in deep-sea sediments from the southwestern Gulf of Mexico
}

\author{
Elva Escobar-Briones ${ }^{1, *}$, Francisco Javier García-Villalobos ${ }^{2,3}$ \\ ${ }^{1}$ Universidad Nacional Autónoma de México, Instituto de Ciencias del Mar y Limnología, Unidad Académica de Ecología Marina, \\ Laboratorio de Biodiversidad y Macroecología. A.P. 70-305, Ciudad Universitaria, Delegación Coyoacán, 04510 México D.F., \\ México. \\ ${ }^{2}$ Universidad Nacional Autónoma de México, Posgrado en Ciencias del Mar y Limnología. Ciudad Universitaria, Delegación \\ Coyoacán 04510 México D.F., México. \\ ${ }^{3}$ Centro de Investigación Científica de Yucatán. Calle 43 No. 130, Col. Chuburná de Hidalgo, 97200 Mérida, Yucatán, México. \\ *escobri@mar.icmyl.unam.mx; escobri@correo.cmarl.unam.mx
}

\begin{abstract}
The temporal and spatial variations of total organic carbon (TOC) and nitrogen (TN) contents, and the carbon-nitrogen ratio in superficial sediments collected at 115 locations at depths between 1,025 and 3,795 m in the Gulf of Mexico during the SIGSBEE, PROMEBIO and DGoMB cruises are herein reported. The average TOC concentration was $0.9 \pm 0.3 \%$, the TN $0.12 \pm 0.03 \%$ and the $\mathrm{C} / \mathrm{N}$ ratio $8.0 \pm 1.7$. None of the typically hemipelagic sediment samples recorded any sulfur. In contrast, chemosynthetic sediment samples from the immediate area of the Chapopote asphalt volcano in the Campeche Bay (3,300 m deep) were significantly higher both in their TOC and TN values than hemipelagic samples, and were characterized by high sulfur contents with local variations associated with bathymetric features in the lower continental slope and the abyssal plain. This study shows that the elemental composition of the abyssal sediments is controlled by depth and follows a parabolic pattern for both TOC and TN. Average values for the continental slope were $\mathrm{TOC}=0.8 \pm 0.2 \%, \mathrm{TN}=0.11 \pm 0.04 \%(\mathrm{n}=39)$, and for the abyssal plain TOC $=1.0 \pm 0.3 \%, \mathrm{TN}=0.12 \pm 0.03 \%(\mathrm{n}=44) . \mathrm{The} \mathrm{C} / \mathrm{N}$ ratio suggests that the organic matter in the superficial sediments has a mixed hemipelagic-terrigenous origin, and it depends on the distance from the coast. This is a major contrast to open-coast gradients where $\mathrm{C} / \mathrm{N}$ ratios remain constant, and thus it is characteristic of a marginal sea. The bathymetry affects TOC and TN, causing significant differences among the physiographic regions. TOC and $\mathrm{TN}$ recorded in a long-term time series station in the abyssal plain displayed changes with time, showing alternating periods of high terrigenous and photoautotrophic input. This study provides evidence of the inter-yearly variability in the origin of the organic matter in the abyssal plain. TOC and TN decrease with depth in the sediment due to the changing sedimentation conditions.
\end{abstract}

Key words: Abyssal plain, continental slope, continental rise, $\mathrm{C} / \mathrm{N}$ ratio, elemental composition.

\section{Resumen}

Este estudio presenta la variabilidad en espacio y tiempo de los valores de contenido de carbono orgánico total (COT), nitrógeno total (NT) y la tasa de carbono-nitrógeno (C/N) en sedimento superficial recolectado en las campañas oceanográficas SIGSBEE, PROMEBIO y DGoMB en 115 localidades del Golfo de México, a profundidades en un intervalo de 1,025 a 3,795 m. La concentración promedio del COT fue de $0.9 \pm 0.3 \%$, la del NT $0.12 \pm 0.03 \%$ y la tasa de C/N 8.0 \pm 1.7 . De las muestras hemipelágicas ninguna registró contenidos de azufre. En contraste, las muestras de sedimento de localidades quimiosintéticas procedentes de las inmediaciones del volcán de asfalto Chapopote en la Bahía de Campeche (3,300 m de profundidad) presentaron valores significativamente más elevados tanto en COT como en NT, y se caracterizaron por presentar azufre. Se encontró una variabilidad a escala local en dichos contenidos relacionada con la topografía de las zonas batimétricas del talud continental inferior y la planicie abisal. Este estudio muestra que la 
composición elemental de los sedimentos abisales está controlada por la profundidad y sigue un patrón parabólico tanto para el COT como para el NT. Los valores promedio del talud continental fueron COT $=0.8 \pm 0.2 \%, N T=0.11 \pm 0.04 \%$ ( $n=39$ ), y para la planicie abisal COT $=1.0 \pm 0.3 \%, N T=0.12 \pm 0.03 \%(n=44)$. La tasa $C / N$ sugiere que la materia orgánica en los sedimentos superficiales tiene un origen mixto hemipelágico-terrígeno, que varía con distancia de la costa. Este resultado contrasta con las tasas $C / N$ observadas en gradientes en mar abierto, que permanecen constantes. Tal variabilidad es característica de un mar marginal. La batimetría afecta los valores de COT y NT, ocasionando diferencias entre regiones fisiográficas. Los valores registrados en la estación abisal de registros de largo plazo muestran cambios en el tiempo, reconociéndose periodos alternantes de aportes terrígenos y fotoautotróficos elevados. Este estudio da evidencias de la variabilidad interanual en el origen de la materia orgánica en la planicie abisal. Los valores de COT y NT disminuyen con la profundidad hacia el interior del sedimento y se atribuyen a condiciones de sedimentación variables.

Palabras clave: Planicie abisal, talud continental, elevación continental, tasa C/N, composición elemental.

\section{Introduction}

The organic matter in sediments, expressed as total organic carbon (TOC) and total nitrogen (TN), represents an important reservoir for the global carbon cycle (Hedges and Keil, 1995; Weston and Joye, 2005). It is linked with early diagenesis (Bordovskiy, 1965b) and plays an important role in the ocean chemistry (Lee, 1994). The largest fraction of carbon entrained in sediments is generated by means of inorganic carbon fixation of atmospheric $\mathrm{CO}_{2}$ by photosynthesis in the water column (Lee, 1994), and only a small fraction $(1.5 \%$ in open ocean primary productivity, $\mathrm{PP}$, and $>17 \%$ on the slope) reaches the sediment, since most of it is oxidized (Seiter et al., 2004). Near $80 \%$ of the carbon is sequestered in the continental margins, thus representing the largest carbon storage in the current world ocean (Wollast, 1998). At the global scale, the storage of organic matter (in terms of TOC) mirrors the distribution pattern of phytoplankton biomass (Seiter et al., 2004). However, at a regional scale, diverse biogeochemical and sediment processes can modify such patterns (Zabel et al., 1998). The preservation efficiency of organic matter in deep-sea sediments is $<0.5 \%$, with a global sequestration rate of $0.16 \times 10^{15} \mathrm{~g} \cdot \mathrm{C} \cdot \mathrm{y}^{-1}$ (Hedges and Keil, 1995); it varies for different sediment types and is controlled by the rate of organic matter production (Stein, 1991), the export rate (Suess, 1980), its origin (Aller and Mackin, 1984) and the amount of dissolved oxygen (Canfield, 1994).

TN plays an important role as a source of nutrients (Fütterer, 2000), decreasing with depth due to the remineralization of organic matter and non-biological oxidation (Stein, 1990; Wakeham, 2002).

Previous studies describing the distribution of organic carbon in deep-sea sediments date back to the 1960s and 1970s (Bordovskiy, 1965a), and were summarized by Premuzic et al. (1982). The maps generated during such studies describe clear patterns, where continental margins are characterized by high organic carbon contents $(>0.5 \%)$ that decrease $(<0.5 \%)$ with distance and depth into the major ocean basins (Seiter et al., 2004). During the last two decades, several studies on this subject focused at a regional scale for the Northern Pacific (Cwienk, 1986), Atlantic (Mollenhauer et al., 2002) and Indian oceans (Vetrov and Romankevich, 1997; Vetrov et al., 1997) have been published. A compilation of diverse studies has been synthesized by Seiter et al. (2004), identifying conditions for regions and provinces of the world ocean.

Among the diverse methods to determine organic matter in the sediments, the elemental analysis allows determination of total and organic carbon fractions, and nitrogen and sulfur. The organic carbon fraction requires the analysis of carbonate-free samples (Stein, 1991). The $\mathrm{C} / \mathrm{N}$ ratio allows determination of the origin of organic matter, based on ratios that are characteristic for different organisms, i.e. the average ratio for zooplankton and phytoplankton is 6 , although it ranges from 4 to 10 according to preferential remineralization of their protein composition (Mayer, 1993), and the average ratio for terrestrial vascular plants is $>15$ (Wakeham, 2002).

This study aims to describe the elemental composition of the superficial sediments of the deep Gulf of Mexico, in view of the patterns described for similar latitudes in open oceans and coasts. This study contributes basic information required for regional balances of carbon and nitrogen fluxes, budgets and cycles. The results will be useful to understand diverse processes affecting the local variability and export of particulated organic matter (POM) with depth, the origin and availability of potential food sources for the deep-sea benthic fauna, and lateral transport, sequestration and early diagenesis in the superficial sediments. All these factors and processes play an important role in tropical deep-sea ecosystems and may modify the expected trends and homogeneous distribution patterns that characterize deep seas.

\section{Area of study}

The Gulf of Mexico is a marginal sea located in the tropical and subtropical zones of the western Atlantic Ocean, at $18-30^{\circ} \mathrm{N}$ latitude and $82-92^{\circ} \mathrm{W}$ longitude (MonrealGómez and Salas de León, 1997). It spans $1,500 \mathrm{~km}$ in 
diameter (Bryant et al., 1991), covers an area of $1.51 \times 10^{6}$ $\mathrm{km}^{2}$ (Wiseman and Sturges, 1999), and is up to $\sim 3,900 \mathrm{~m}$ deep (Roberts et al., 1999).

The primary productivity varies from eutrophic conditions near the coast and during winters to oligotrophic in offshore waters and during summers (Lohrenz et al., 1999). Its major mesoscale hydrographic features are: $(a)$ the Loop Current, $(b)$ the large anticyclonic and cyclonic gyres shed to the west that occur on the Texas-Louisiana and Florida shelves and on the Campeche Bay, and (c) the fronts off the Mississippi and Grijalva-Usumacinta rivers (Monreal-Gómez and Salas de León, 1997).

The Gulf of Mexico deep-sea waters are similar to the Deep Atlantic Water, varying only in its nutrient and oxygen concentration $\left(220 \mu \mathrm{mol} \cdot \mathrm{kg}^{-1}\right.$; Shiller, 1999) through its transport in the deep Caribbean Sea. This deep water mass is characterized by salinities of 34.96-34.99 psu and temperatures of $4.0-4.1^{\circ} \mathrm{C}$ that are homogeneous at depths below 1,500 m (Shiller, 1999).

Three major geological provinces are characterized in the Gulf of Mexico by their morphology, tectonics and sediment types, and are divided into nine physiographic regions (Bryant et al., 1991). Offshore sediments are finegrained and pelagic or carbonated in origin; off Florida and the Campeche Bank sediments are mostly carbonated, whereas terrigenous sediments characterize the TexasLouisiana-Mississippi and western continental slopes (Balsam and Beeson, 2003). The only published information on the organic matter content in the Gulf of Mexico is from Balsam and Beeson (2003), who indicated the large contribution of organic matter to superficial sediments.

\section{Methodology}

\subsection{Fieldwork}

Superficial sediment samples were collected at a depth range of 1,025 to $3,750 \mathrm{~m}$ onboard UNAM's R/V Justo Sierra (SIGSBEE.1 to .8; PROMEBIO.1 to .3 cruises) and TAMU's R/V Gyre (DGoMB cruise) in the summer of years 1997 to 2005 (Figure 1, Table 1). The samples were collected from the top $5 \mathrm{~cm}$ of sediments, with a US-NEL boxcorer during the SIGSBEE. 1 to .5 and PROMEBIO. 1 to .3 cruises, with a multiple corer on the SIGSBEE. 6 to .8 cruises, and with a GOMEX boxcorer on the DGoMB cruise. During the SIGSBEE. 8 cruise, centimeter by centimeter vertical segmentation of the core was performed. The sediment samples were frozen onboard in labeled $25 \mathrm{~mL}$ centrifuge tubes at $-20^{\circ} \mathrm{C}$.

\subsection{Sample processing}

The sediment samples were thawed at room temperature, placed in glass jars with distilled water and acidified with $0.2 \mathrm{~N} \mathrm{HCl}$ to eliminate the inorganic fraction. The $\mathrm{pH}$ was monitored throughout the process. Acidified samples were dried at $60^{\circ} \mathrm{C}$, homogenized and prepared in capsules for elemental analyses (EA) in a FISONS EA1108 analyzer. Accuracy and precision were determined for the EA procedure and cystine was used as the calibration standard.

\subsection{Data treatment}

\subsubsection{Variability of the sediment elemental composition}

TOC, $\mathrm{TN}$ and the $\mathrm{C} / \mathrm{N}$ ratio were determined for different depth zones (continental slope, continental rise, and abyssal plain). The value interval, the mean and standard deviation were determined. The continental slope was considered within the depth range between 1,000 and 2,800 m (Pequegnat, 1970; Coleman et al., 1991; Roberts et al., 1999), the continental rise was considered from the outer limit of the continental slope to a depth of 3,600 $\mathrm{m}$, and deeper zones were considered part of the abyssal plain (Pequegnat, 1970; Bryant et al., 1991). The U MannWhitney test allowed the identification of differences in the elemental values among the three depth intervals, after testing the datasets with an ANOVA Kruskal-Wallis test.

\subsubsection{Variability with distance from the coast}

The terrigenous input from the coastal zone to the deep sea was evaluated on samples obtained along three transects from SIGSBEE cruises 3, 4 and 5 (Figure 2). The distance from the coast was determined with the DTCC 4.1 software. The Spearman correlation test allowed the evaluation of the change of TOC, TN and $\mathrm{C} / \mathrm{N}$ ratios with distance from the coast.

\subsubsection{Variability by physiographic regions}

The sampling stations are located in the nine physiographic regions described by Bryant et al. (1991) (Figure 1; Table 1). Their differences were evaluated with a U Mann-Whitney test.

\subsubsection{Inter-yearly TN variability: the Sigsbee abyssal plain permanent station}

The inter-yearly consistency in the elemental composition of the abyssal plain was evaluated from samples collected in a long term time series station located at $23^{\circ}$ latitude $\mathrm{N}$ and $93^{\circ}$ longitude $\mathrm{W}$ for the years 2002, 2003, 2004 and 2005. A Spearman correlation test was used to test the variability with time of the studied factors.

\subsubsection{Variability in response to the sedimentation conditions}

Vertical segmentation, centimeter by centimeter, of four cores collected at stations $1,3,5$, and 8 of the SIGSBEE. 8 cruise, was performed to evaluate the variability of the $\mathrm{C}$ and $\mathrm{N}$ elemental composition with depth in the sediments. A Spearman correlation test was used to evaluate the variability of the TOC, TN and the $\mathrm{C} / \mathrm{N}$ ratio with depth. 


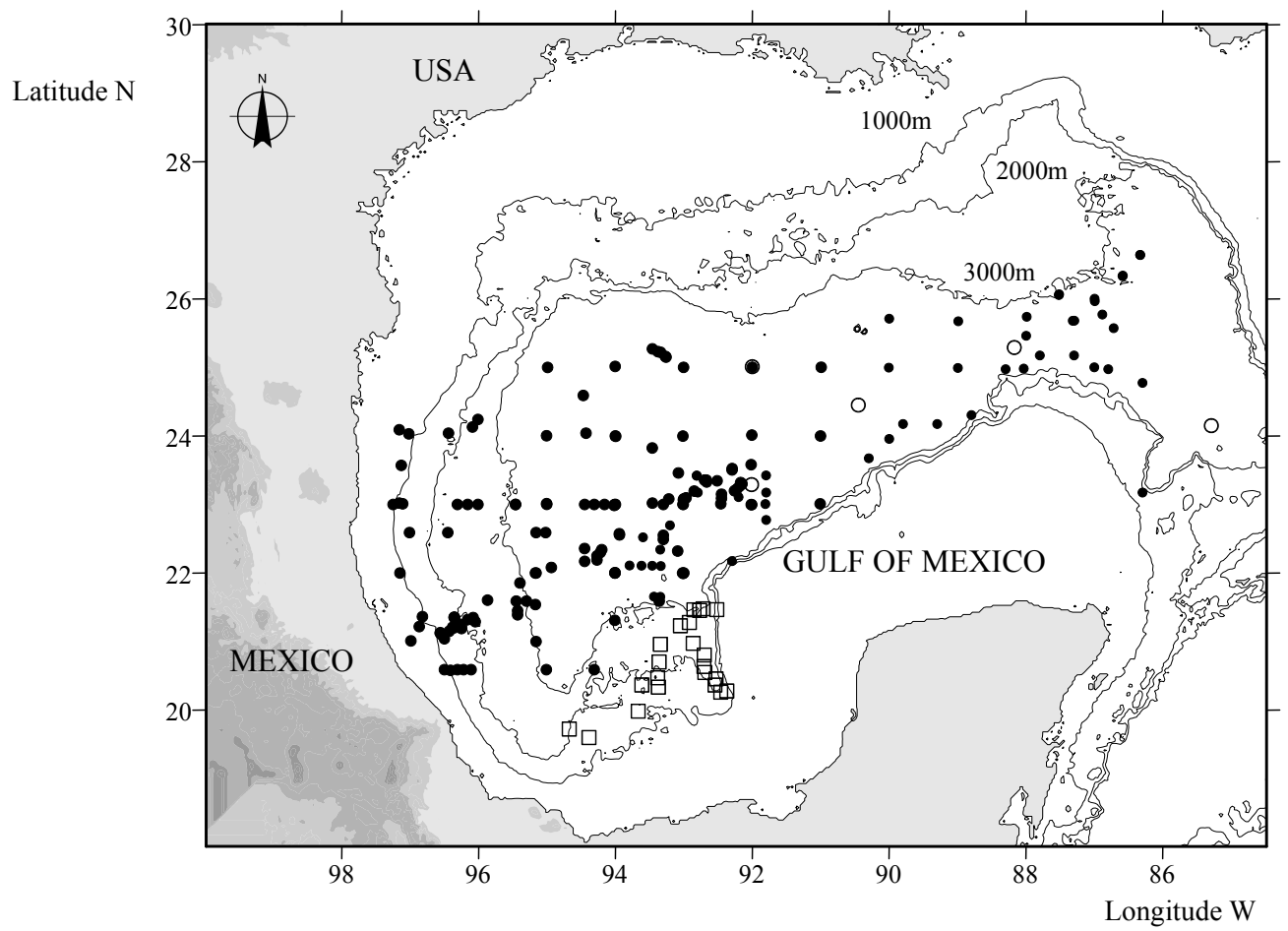

Figure 1. Study area and sampling stations. Solid circles = SIGSBEE cruises; open squares $=$ PROMEBIO cruises; open circles $=$ DGoMB cruises. Transects from west to east off the eastern Mexican coast.

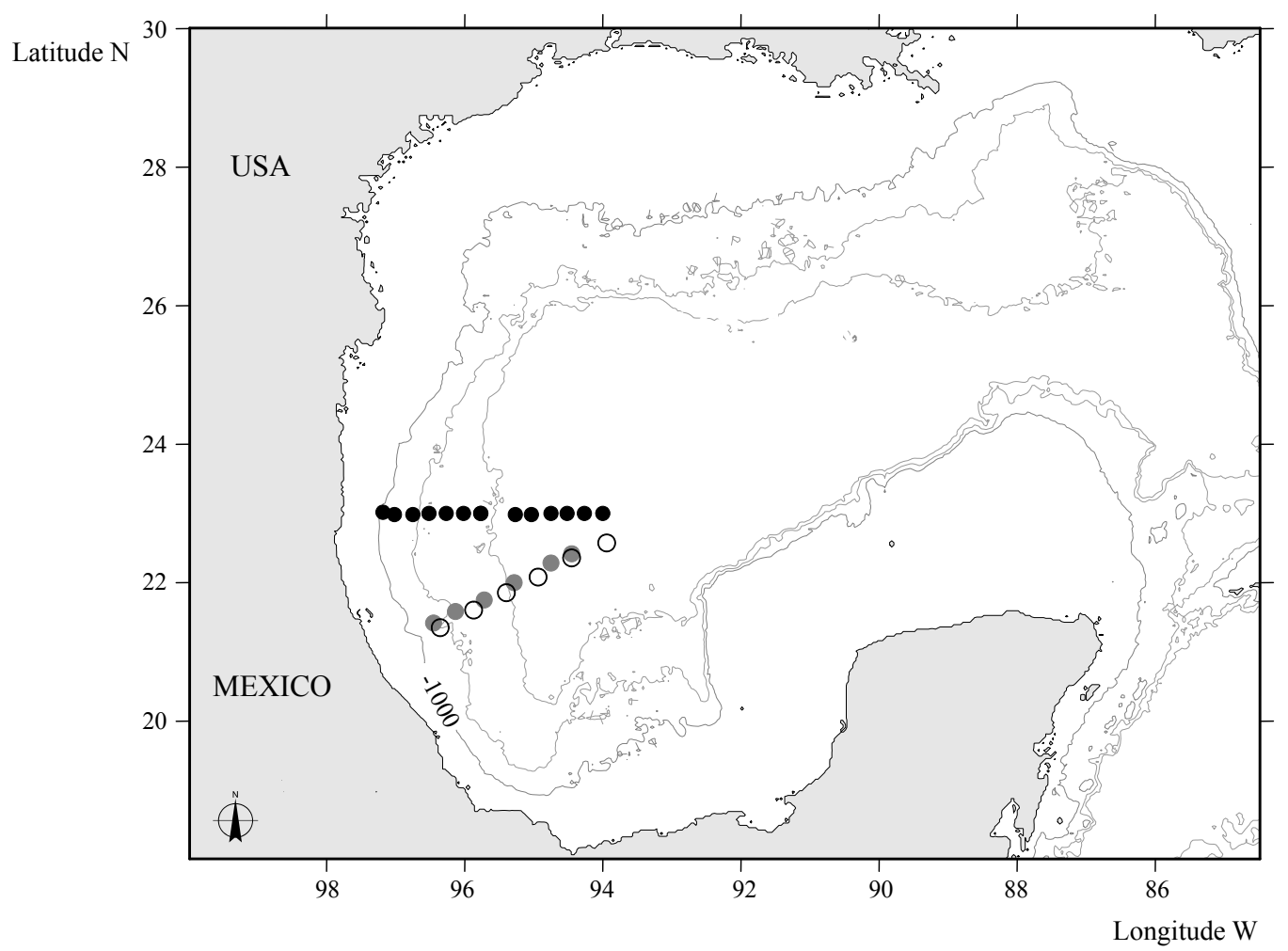

Figure 2. Stations analyzed for the coast distance elemental composition variability: SIGSBEE.3 with solid black markers, SIGSBEE.4 with solid grey markers, SIGSBEE.5 with white markers. 
Table 1. Location of the sampling stations.

\begin{tabular}{|c|c|c|c|c|c|}
\hline Cruise & Year & Station & $\begin{array}{c}\text { Longitude } \\
\text { W }\left({ }^{\circ}\right)\end{array}$ & $\begin{array}{c}\text { Latitude } \\
\mathbf{N}\left({ }^{\circ}\right) \\
\end{array}$ & $\begin{array}{c}\text { Depth } \\
\text { (m) }\end{array}$ \\
\hline \multirow{6}{*}{ SIGSBEE.1 } & \multirow{6}{*}{1997} & 3 & 96.44 & 24.04 & 1,260 \\
\hline & & 4 & 97.16 & 24.09 & 1,698 \\
\hline & & 5 & 96.09 & 24.13 & 2,220 \\
\hline & & 6 & 96.01 & 24.24 & 2,662 \\
\hline & & 9 & 93.26 & 25.15 & 3,620 \\
\hline & & 10 & 94.47 & 24.59 & 3,700 \\
\hline \multirow{14}{*}{ SIGSBEE. 2} & \multirow{14}{*}{1999} & 4 & 96.31 & 20.59 & 1,400 \\
\hline & & 5 & 96.22 & 20.59 & 1,680 \\
\hline & & 7 & 95.45 & 21.59 & 2,300 \\
\hline & & 8 & 95.3 & 21.59 & 2,730 \\
\hline & & 9 & 95.16 & 21 & 2,900 \\
\hline & & 10 & 95.01 & 20.59 & 3,360 \\
\hline & & 13 & 93.36 & 21.59 & 3,300 \\
\hline & & 14 & 93.09 & 22.32 & 3,600 \\
\hline & & 16 & 92.17 & 23.32 & 3,795 \\
\hline & & 17 & 93.22 & 23.08 & 3,730 \\
\hline & & 18 & 94.22 & 22.3 & 3,750 \\
\hline & & 19 & 95.16 & 22 & 3,200 \\
\hline & & 20 & 96.16 & 21.32 & 1,960 \\
\hline & & 21 & 96.36 & 21.2 & 1,400 \\
\hline \multirow{17}{*}{ SIGSBEE. 3} & \multirow{17}{*}{2000} & 3 & 97.11 & 23.01 & 1,157 \\
\hline & & 4 & 97.01 & 22.59 & 1,510 \\
\hline & & 5 & 96.45 & 22.59 & 1,779 \\
\hline & & 6 & 96.31 & 23 & 2,210 \\
\hline & & 7 & 96.16 & 23 & 2,440 \\
\hline & & 8 & 96.01 & 23 & 2,524 \\
\hline & & 9 & 95.46 & 23 & 2,750 \\
\hline & & 10 & 95.46 & 23 & 3,200 \\
\hline & & 11 & 95.16 & 22.59 & 3,380 \\
\hline & & 12 & 95.02 & 22.59 & 3,630 \\
\hline & & 13 & 94.45 & 23 & 3,680 \\
\hline & & 14 & 94.31 & 23 & 3,720 \\
\hline & & 15 & 94.16 & 23 & 3,765 \\
\hline & & 16 & 94 & 23 & 3,760 \\
\hline & & 17 & 93.46 & 23.02 & 3,775 \\
\hline & & 18 & 93.3 & 23 & 3,740 \\
\hline & & 19 & 94.2 & 22.34 & 3,730 \\
\hline \multirow{7}{*}{ SIGSBEE.4 } & \multirow{7}{*}{2001} & 3 & 96.27 & 21.25 & 1,500 \\
\hline & & 4 & 96.08 & 21.35 & 2,100 \\
\hline & & 5 & 95.43 & 21.45 & 2,500 \\
\hline & & 6 & 95.17 & 22 & 3,000 \\
\hline & & 7 & 94.45 & 22.17 & 3,500 \\
\hline & & 8 & 94.27 & 22.25 & 3,700 \\
\hline & & 9 & 93.3 & 22.55 & 3,700 \\
\hline \multirow{11}{*}{ SIGSBEE. 5} & \multirow{11}{*}{2002} & 1 & 92.02 & 23.58 & 3,710 \\
\hline & & 2 & 92.3 & 23.5 & 3,740 \\
\hline & & 3 & 92.51 & 23.35 & 3,720 \\
\hline & & 4 & 93 & 23.08 & 3,720 \\
\hline & & 5 & 93.46 & 23.82 & 3,720 \\
\hline & & 6 & 93.94 & 22.57 & 3,700 \\
\hline & & 7 & 94.45 & 22.36 & 3,660 \\
\hline & & 8 & 94.94 & 22.08 & 3,420 \\
\hline & & 9 & 95.4 & 21.85 & 3,000 \\
\hline & & 10 & 95.87 & 21.6 & 2,500 \\
\hline & & 11 & 96.35 & 21.35 & 1,860 \\
\hline \multirow{2}{*}{ SIGSBEE.6 } & \multirow{2}{*}{2003} & 1 & 90.99 & 25 & 3,542 \\
\hline & & 2 & 91 & 24 & 3,710 \\
\hline
\end{tabular}

\begin{tabular}{|c|c|c|c|c|c|}
\hline Cruise & Year & Station & $\begin{array}{c}\text { Longitude } \\
\text { W }\left({ }^{\circ}\right)\end{array}$ & $\begin{array}{c}\text { Latitude } \\
\text { N }\left({ }^{\circ}\right)\end{array}$ & $\begin{array}{c}\text { Depth } \\
\text { (m) }\end{array}$ \\
\hline \multirow{15}{*}{ SIGSBEE.6 } & \multirow{15}{*}{2003} & 3 & 91.01 & 23.01 & 3,718 \\
\hline & & 4 & 92.02 & 23 & 3,739 \\
\hline & & 5 & 92.01 & 24.01 & 3,700 \\
\hline & & 6 & 92 & 25 & 3,532 \\
\hline & & 7 & 93 & 25 & 3,634 \\
\hline & & 8 & 93.01 & 24 & 3,736 \\
\hline & & 9 & 93.01 & 23 & 3,744 \\
\hline & & 10 & 94.01 & 23 & 3,742 \\
\hline & & 11 & 94 & 24 & 3,740 \\
\hline & & 12 & 94 & 25.01 & 3,698 \\
\hline & & 13 & 94.99 & 25 & 3,578 \\
\hline & & 14 & 95.01 & 24 & 3,575 \\
\hline & & 15 & 95.01 & 23.01 & 3,560 \\
\hline & & 16 & 94.01 & 22 & 3,563 \\
\hline & & 16 bis & 93.01 & 21.99 & 3,326 \\
\hline \multirow{6}{*}{ SIGSBEE.7 } & \multirow{6}{*}{2004} & 1 & 93 & 23.07 & 3,740 \\
\hline & & 2 & 92.85 & 23.2 & 3,734 \\
\hline & & 3 & 92.67 & 23.36 & 3,664 \\
\hline & & 4 & 92.7 & 23.36 & 3,651 \\
\hline & & 5 & 92.67 & 23.33 & 3,654 \\
\hline & & 6 & 94.02 & 22.99 & 3,734 \\
\hline \multirow{11}{*}{ SIGSBEE. 8} & \multirow{11}{*}{2005} & 1 & 87 & 25 & 3,344 \\
\hline & & 2 & 87 & 26 & 3,171 \\
\hline & & 3 & 87.99 & 25.74 & 3,166 \\
\hline & & 4 & 88.03 & 24.98 & 3,430 \\
\hline & & 5 & 88.99 & 24.99 & 3,495 \\
\hline & & 6 & 88.99 & 25.67 & 3,264 \\
\hline & & 7 & 90 & 25.71 & 3,282 \\
\hline & & 8 & 90 & 25 & 3,529 \\
\hline & & 9 & 90 & 23.96 & 3,631 \\
\hline & & 10 & 92 & 23 & 3,737 \\
\hline & & 11 & 93 & 23 & 3,740 \\
\hline \multirow{5}{*}{ DGoMB } & \multirow{5}{*}{2000} & 1 & 92 & 25.01 & 3,520 \\
\hline & & 2 & 92.01 & 23.29 & 3,733 \\
\hline & & 3 & 90.45 & 24.45 & 3,670 \\
\hline & & 4 & 85.29 & 24.15 & 3,405 \\
\hline & & 5 & 88.17 & 25.29 & 3,316 \\
\hline \multirow{16}{*}{ PROMEBIO 1} & \multirow{16}{*}{1999} & 2 & 92.85 & 21.58 & 3,020 \\
\hline & & 3 & 92.78 & 21.60 & 3,050 \\
\hline & & 5 & 92.59 & 21.59 & 2,500 \\
\hline & & 9 & 92.99 & 21.10 & 2,900 \\
\hline & & 11 & 92.93 & 21.10 & 2,840 \\
\hline & & 15 & 93.41 & 21.08 & 2,480 \\
\hline & & 20 & 92.77 & 20.92 & 2,750 \\
\hline & & 25 & 92.77 & 20.76 & 2,420 \\
\hline & & 26 & 92.76 & 20.67 & 2,560 \\
\hline & & 30 & 93.43 & 20.82 & 2,460 \\
\hline & & 31 & 93.45 & 20.59 & 1,800 \\
\hline & & 32 & 93.44 & 20.46 & 1,820 \\
\hline & & 36 & 92.61 & 20.58 & 2,460 \\
\hline & & 37 & 92.61 & 20.49 & 2,420 \\
\hline & & 38 & 92.53 & 20.38 & 2,320 \\
\hline & & 39 & 92.43 & 20.40 & 1,600 \\
\hline \multirow{3}{*}{ PROMEBIO 2} & \multirow{3}{*}{1999} & 17 & 94.52 & 19.10 & 1,094 \\
\hline & & 40 & 93.80 & 19.48 & 1,025 \\
\hline & & 144 & 94.81 & 19.22 & 1,758 \\
\hline \multirow{2}{*}{ PROMEBIO 3} & \multirow{2}{*}{2000} & 123 & 93.01 & 21.01 & 2,520 \\
\hline & & 132 & 93.57 & 20.14 & 2,243 \\
\hline
\end{tabular}




\section{Results}

\subsection{Total Organic Carbon (TOC)}

\subsubsection{Variability of the sediment elemental composition}

The TOC values range from 0.260 to $1.800 \%$ with a mean value of $0.9 \%$ and a standard deviation of $0.3 \%$ for the 115 sampling locations in a depth interval of 1,025 to 3,975 $\mathrm{m}$. These values are not linearly related to depth (Figure 3, Table 2). The values were relatively low in the continental slope sediments $(\mathrm{TOC}=0.9 \pm 0.2 \%, \mathrm{n}=39)$, and increased within the continental rise ( $\mathrm{TOC}=1.0 \pm 0.3 \%, \mathrm{n}=32)$ and the abyssal plain (TOC $=1.0 \pm 0.3 \%, \mathrm{n}=44)$. Significant differences were recorded among the three depth intervals (ANOVA Kruskal-Wallis: $\mathrm{H}=6.83, \mathrm{p}=0.03 ; \chi^{2}=6.53, \mathrm{p}=$ $0.03)$, between the continental slope and the continental rise (U Mann-Whitney: $Z_{-1.73}=1.73, \mathrm{p}=0.08$ ), and between the continental slope and the abyssal plain (U Mann-Whitney: $\left.Z_{-2.50}=-2.50, p=0.01\right)$.

\subsubsection{Variability with distance from the coast}

The TOC values decrease with the distance from the coast (Figure 4; Wald-Wolfgovits: $Z_{2.20}=-2.40, \mathrm{p}=0.01$ ). These differences were significant for the transect off Tamiahua (Wald-Wolfgovits: $Z_{1.23}=-1.76, p=0.07$ ). On the contrary, the TOC values from the transect off Tuxpan displayed a direct correlation with distance from the coast (Spearman: $\mathrm{R}=1, \mathrm{p}=0.01$, explaining $91 \%$ of the cases, $\left.\mathrm{r}^{2}=0.91\right)$.

\subsubsection{Variability by physiographic regions}

The lowest TOC concentrations were found in the continental slope of the western Gulf of Mexico (TOC = $0.8 \pm 0.2 \%, \mathrm{n}=22)$, in contrast with the values recorded in the Campeche Knolls (TOC $=0.9 \pm 0.1 \%, \mathrm{n}=11$ ), in the Campeche Canyon (TOC $=0.9 \pm 0.3 \%, \mathrm{n}=10$ ), and in the Mississippi Fan (TOC $=0.9 \pm 0.3 \%, n=10$ ) (Figure $5)$. The highest values were recorded on the continental rise of the Campeche Sound (TOC $=1.0 \pm 0.3 \%, \mathrm{n}=12$ ), the Sigsbee abyssal plain (TOC $=1.0 \pm 0.3 \%, \mathrm{n}=44$ ), the continental slope off Veracruz $(\mathrm{TOC}=1.1 \pm 0.4 \%, \mathrm{n}=3$ ), and the Campeche Escarpment $(\mathrm{TOC}=1.1-0.5 \%)$. The differences among the nine physiographic regions were not significant (ANOVA Kruskal-Wallis: $\mathrm{H}=6.83, \mathrm{p}=0.03$; $\left.\chi^{2}=6.53, \mathrm{p}=0.03\right)$.

\subsubsection{Interyearly TOC variability: the Sigsbee abyssal plain permanent station}

The TOC values in the abyssal plain varied from $1.6 \%$ in 2003 to $0.8 \%$ in 2005 (Figure 6). These differences were not significant (ANOVA Kruskal-Wallis: $\mathrm{H}=2.66, \mathrm{p}<0.44$; $\left.\chi^{2}=4.00, \mathrm{p}<0.26\right)$.

\subsubsection{TOC variability in response to the sedimentation conditions}

The TOC values at three stations (E1, E5, and E8, SIGSBEE. 8 cruise) decrease with depth in the sediment (Spearman: $\mathrm{R}=0.956, \mathrm{R}=0.985$ and $\mathrm{R}=0.886$; $\mathrm{p}<0.05$ ). The TOC values at station E3, near the Mississippi Canyon, did not show any correlation with depth in the sediment (Figure 7).

\subsection{Nitrogen $(\mathrm{TN})$}

\subsubsection{Variability of the sediment elemental composition}

The TN concentration ranges from 0.040 to $0.250 \%$ in the superficial sediments, with a mean value of $0.12 \%$ and standard deviation of $0.03 \%$ in the 115 stations sampled at depths from 1,025 to $3,975 \mathrm{~m}$. The TN concentration in superficial sediments displays a polynomial pattern with increasing depth (Figure 3, Table 2). TN displays low values in the continental slope $(\mathrm{N}=0.12 \pm 0.04 \%, \mathrm{n}=39)$ and in the continental rise stations $(\mathrm{N}=0.12 \pm 0.03 \%, \mathrm{n}=32)$. $\mathrm{TN}$ concentrations in the abyssal plain station are slightly higher $(\mathrm{N}=0.13 \pm 0.03 \%, \mathrm{n}=44)$, without significant differences among different depth zones (ANOVA Kruskal-Wallis: H $\left.=3.93, \mathrm{p}=0.14 ; \chi^{2}=4.47, \mathrm{p}=0.11\right)$.

\subsubsection{Variability with distance from the coast}

$\mathrm{TN}$ varies with distance from the coast (Figure 4) in the transects off Barra del Tordo (SIGSBEE.3; WaldWolfovits: $Z_{1.94}=-2.22, \mathrm{p}=0.02$ ), off Tuxpan (SIGSBEE.4; Spearman: $\left.\mathrm{R}=0.88, \mathrm{p}=0.01 ; \mathrm{r}^{2}=0.71\right)$, and off Tamiahua (SIGSBEE.5; Spearman: $\mathrm{R}=0.94, \mathrm{p}=0.04 ; \mathrm{r}^{2}=0.70$ ).

\subsubsection{TN variability by physiographic regions}

$\mathrm{TN}$ varies among the nine physiographic regions. The western continental slope and the Campeche Canyon have similar values $(\mathrm{TN}=0.11 \pm 0.03 \%, \mathrm{n}=22$, and $\mathrm{TN}=0.11$ $\pm 0.04 \%, \mathrm{n}=10$, respectively) (Figure 8 ). $\mathrm{TN}$ is higher in the Mississippi Fan (TN $=0.12 \pm 0.03 \%, \mathrm{n}=10)$ and in the continental rise of the SW Gulf of Mexico ( $\mathrm{TN}=0.12$ $\pm 0.03 \%, \mathrm{n}=12)$. High TN values were recorded in the Sigsbee abyssal plain $(\mathrm{TN}=0.13 \pm 0.03, \mathrm{n}=44)$ and in the Campeche continental slope and Knolls $(\mathrm{TN}=0.13 \pm 0.04 \%$, $\mathrm{n}=11)$. Three stations on the Veracruz slope displayed the highest values $(\mathrm{TN}=0.19 \pm 0.03 \%)$, followed by the Campeche Escarpment $(\mathrm{TN}=0.14 \pm 0.08 \%)$. Significant differences were recorded in the continental slopes of the western Gulf of Mexico and off Veracruz (U Mann-Whitney: $\left.\mathrm{Z}_{(-2.34)}=2.34, \mathrm{p}=0.02\right)$, in the Sigsbee abyssal plain $\left(\mathrm{Z}_{(-2.58)}\right.$ $=-2.58, \mathrm{p}=0.01)$, in the Campeche continental slope $\left(Z_{(-}\right.$ $\left.{ }_{1.68)}=1.68, \mathrm{p}=0.09\right)$, and in the continental rise $\left(Z_{(-1.78)}=\right.$ $-1.78, p=0.07)$. The other NT values showed no significant differences (ANOVA Kruskal-Wallis: $\mathrm{H}=3.93, \mathrm{p}=0.14$; $\left.\chi^{2}=4.47, \mathrm{p}=0.11\right)$.

\subsubsection{Interyearly TN variability: the Sigsbee abyssal plain permanent station}

The $\mathrm{TN}$ values recorded changes between years (Figure $6)$. The highest values were recorded in $2003(\mathrm{TN}=0.17 \%)$ 

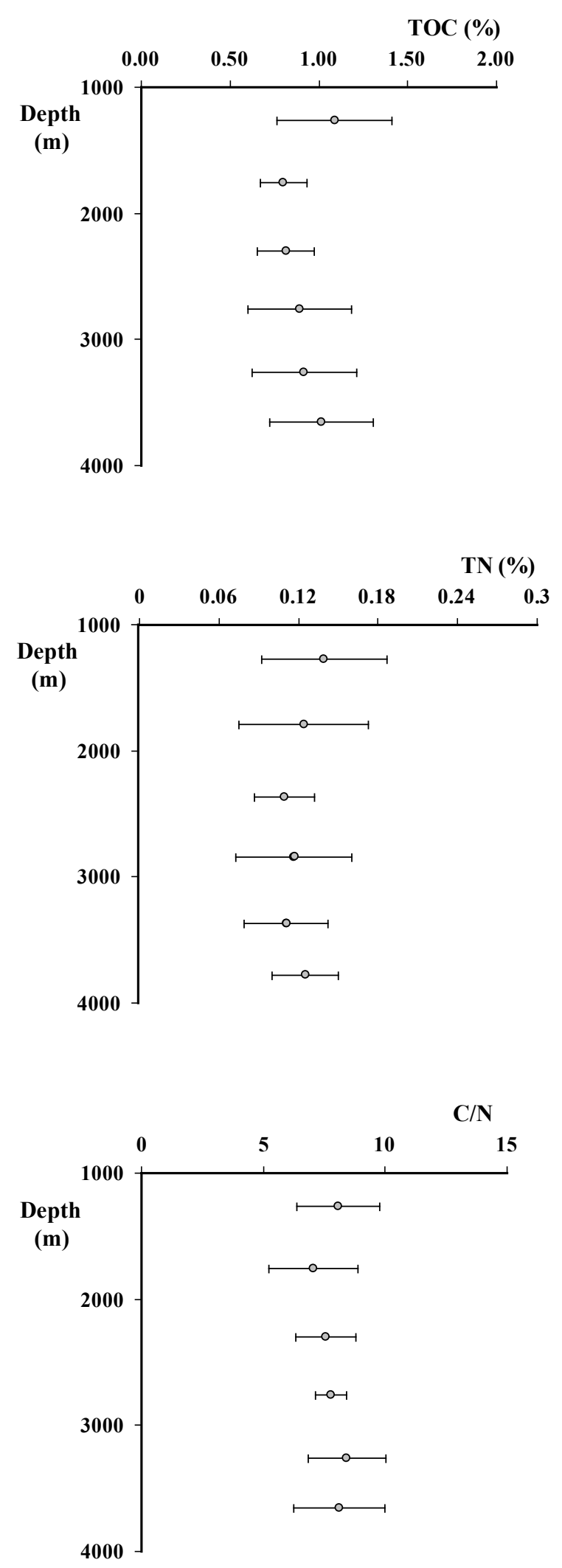

Figure 3. Plot of TOC, TN and $\mathrm{C} / \mathrm{N}$ in the basin sediments $v s$. depth.

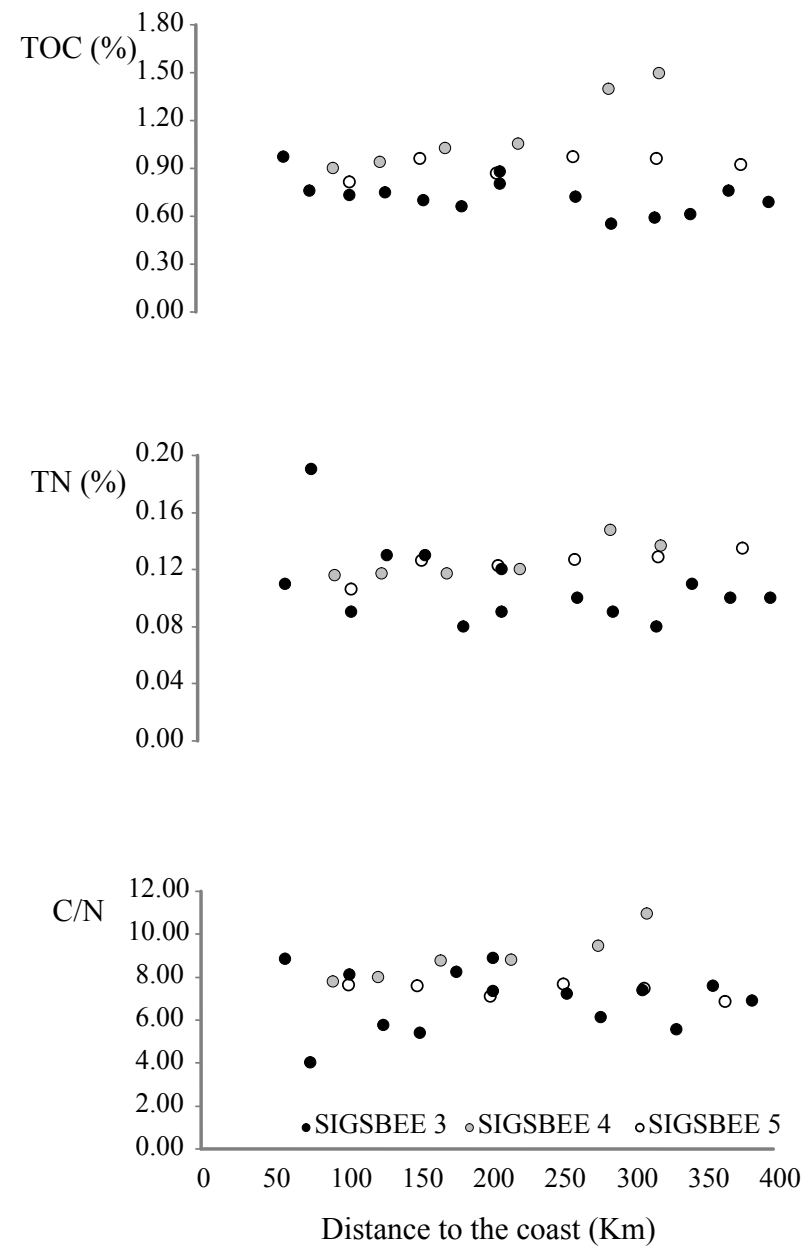

Figure 4. Variation of C/N, TOC and TN in the basin sediments with respect to the distance to the coast, for three cruise samples.

Table 2. Sediment TOC, $\mathrm{TN}$ and $\mathrm{C} / \mathrm{N}$ in the southwestern Gulf of Mexico. Abbreviations used: Mean (x), standard deviation (s), maximum value $(\max )$ and minimum value (min), number of replicated records (n). Cruise names: SIGSBEE (S), PROMEBIO (PRO) and DGoMB.

\begin{tabular}{|c|c|c|c|c|c|c|c|}
\hline Depth Zone & $\begin{array}{c}\text { Depth } \\
\text { (m) }\end{array}$ & Statistics & $\begin{array}{c}\text { TOC } \\
(\%)\end{array}$ & $\begin{array}{l}\mathrm{N} \\
(\%)\end{array}$ & $\mathrm{C} / \mathrm{N}$ & $\mathrm{n}$ & Cruises \\
\hline $\begin{array}{l}\text { Continental } \\
\text { Slope } \\
\text { (Bathyal) }\end{array}$ & $\begin{array}{c}1,025 \\
- \\
2,750\end{array}$ & $\begin{array}{c}\mathrm{x} \\
\mathrm{s} \\
\max \\
\min \end{array}$ & $\begin{array}{l}0.862 \\
0.230 \\
1.780 \\
0.485\end{array}$ & $\begin{array}{l}0.118 \\
0.038 \\
0.230 \\
0.070\end{array}$ & $\begin{array}{c}7.557 \\
1.406 \\
10.540 \\
3.727\end{array}$ & 39 & $\begin{array}{l}\text { PRO1, PRO2, } \\
\text { S1, S2, S3, } \\
\text { S4, S5 }\end{array}$ \\
\hline $\begin{array}{l}\text { Continental } \\
\text { Rise }\end{array}$ & $\begin{array}{c}2,840 \\
- \\
3,578\end{array}$ & $\begin{array}{c}\mathrm{x} \\
\mathrm{s} \\
\max \\
\min \end{array}$ & $\begin{array}{l}0.966 \\
0.184 \\
1.609 \\
0.375\end{array}$ & $\begin{array}{l}0.117 \\
0.034 \\
0.230 \\
0.040\end{array}$ & $\begin{array}{c}8.370 \\
1.399 \\
13.083 \\
6.793\end{array}$ & 32 & $\begin{array}{l}\text { DGoMB, } \\
\text { PRO1, S2, S3, } \\
\text { S4, S5, S6, S8 }\end{array}$ \\
\hline Abyssal Plain & $\begin{array}{c}3,600 \\
- \\
3,795\end{array}$ & $\begin{array}{c}\mathrm{x} \\
\mathrm{s} \\
\max \\
\min \end{array}$ & $\begin{array}{l}1.004 \\
0.310 \\
1.575 \\
0.260\end{array}$ & $\begin{array}{l}0.125 \\
0.027 \\
0.178 \\
0.075\end{array}$ & $\begin{array}{c}8.039 \\
1.978 \\
11.883 \\
3.250\end{array}$ & 44 & $\begin{array}{l}\text { DGoMB, S1, } \\
\text { S2, S3, S4, S5, } \\
\text { S6, S7, S8 }\end{array}$ \\
\hline
\end{tabular}




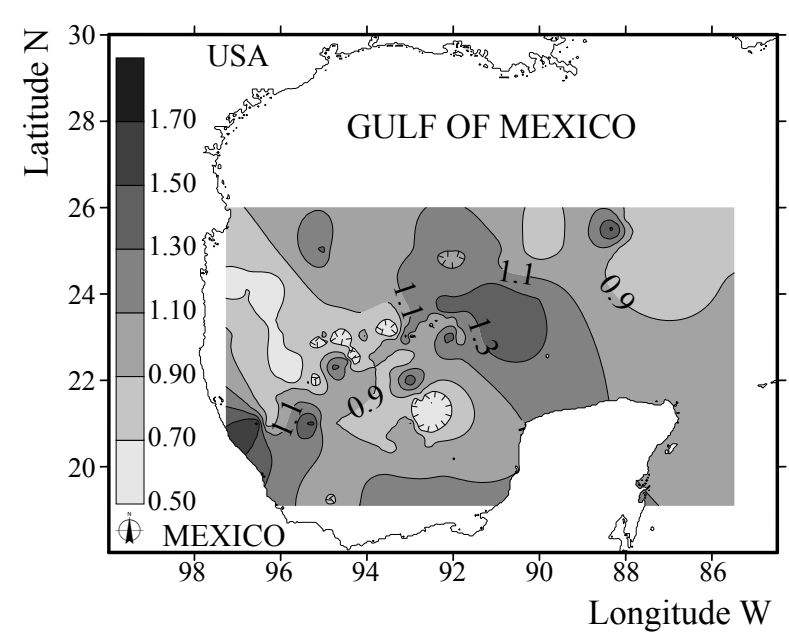

Figure 5. Sediment TOC concentration isopletes. Values in percentage.

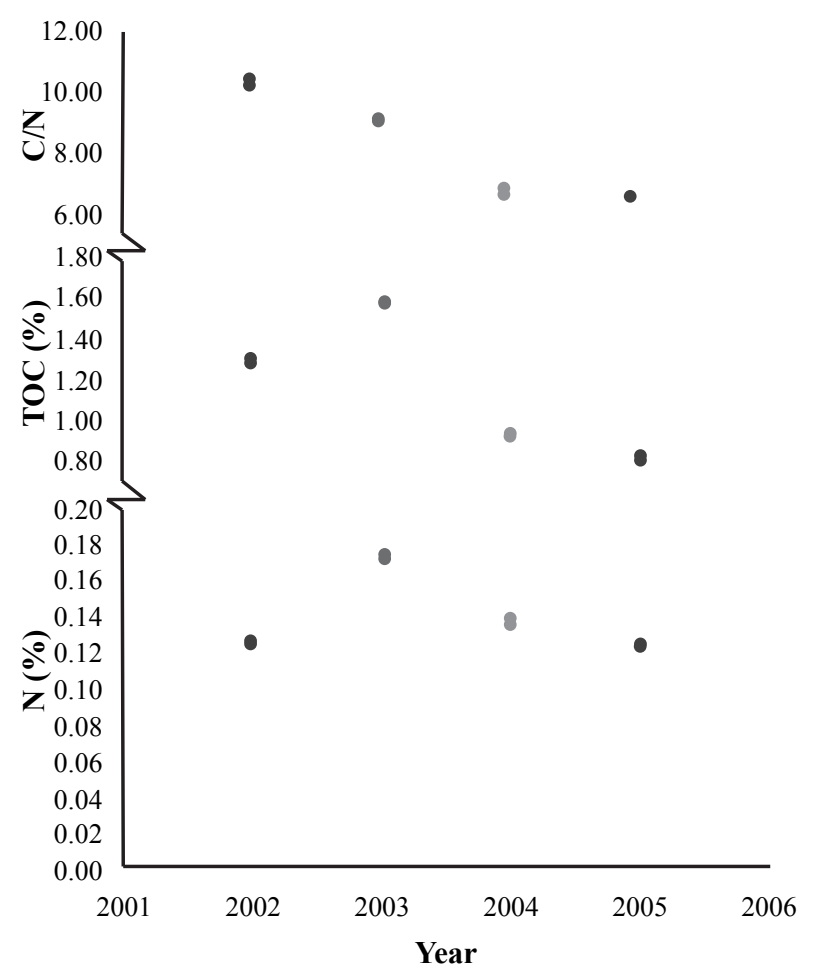

Figure 6. Inter-yearly variability of the sediment TOC, TN and $\mathrm{C} / \mathrm{N}$ in the time series long term ecological research station.

and the lowest in $2005(\mathrm{TN}=0.12 \%)$, but such differences are not significant (ANOVA Kruskal-Wallis: $\mathrm{H}=6.66, \mathrm{p}<$ $\left.0.08 ; \chi^{2}=8.00, \mathrm{p}<0.05\right)$.

\subsubsection{TN variability in response to the sedimentation conditions}

The TN concentrations (Figure 7) in three of the four
Sigsbee abyssal plain stations (E1, E5 and E8; SIGSBEE.8 cruise) correlate with depth in the sediment (Spearman: $\mathrm{R}$ $=0.886, \mathrm{R}=0.9354, \mathrm{R}=0.9847, \mathrm{p}<0.05$ ).

\subsection{Carbon-Nitrogen ratio}

TOC shows a direct relation with $\mathrm{TN}$ in the superficial sediments of the deep Gulf of Mexico (ANOVA: F1,224 = 204; $\mathrm{p}<0.001$ ), and adjusts to a linear regression with a correlation coefficient that explains $54 \%$ of the cases $\left(\mathrm{r}^{2}=\right.$ 0.54; Figure 9) for the SIGSBEE stations and $53 \%$ for the DGoMB stations $\left(r^{2}=0.53\right)$. The samples with the highest TOC were collected in the Campeche Canyon and in the Sigsbee Knolls, in the abyssal plain, during the PROMEBIO cruises, and do not show any linear correlation.

\subsubsection{Variability of the sediment elemental composition}

The carbon-nitrogen ratio $(\mathrm{C} / \mathrm{N})$ for the 115 samples, from depths of 1,025 to $3,975 \mathrm{~m}$, has a mean value of 7.9 with a standard deviation of 1.7 (Figure 3, Table 2). C/N does not change with increasing depth. The lowest $\mathrm{C} / \mathrm{N}$ ratios are observed on the continental slope $(\mathrm{C} / \mathrm{N}=7.6 \pm 1.4, \mathrm{n}=39)$, and the highest on the continental rise $(\mathrm{C} / \mathrm{N}=8.4 \pm 1.4, \mathrm{n}$ $=32)$, decreasing in the abyssal plain $(\mathrm{C} / \mathrm{N}=8.0 \pm 2.0, \mathrm{n}=$ 44). These values are not significantly different (ANOVA Kruskal-Wallis: $\mathrm{H}=3.42, \mathrm{p}=0.18 ; \chi^{2}=2.99, \mathrm{p}=0.22$ ).

\subsection{2. $C / N$ variability with distance to the coast}

$\mathrm{C} / \mathrm{N}$ varies with distance to the coast for the transects analyzed in this study (Spearman: $\mathrm{R}=1, \mathrm{p}=0.01 ; \mathrm{r}^{2}=0.91$, explaining $91 \%$ of the cases) (Figure 4 ).

\subsection{3. $C / N$ variability by physiographic region}

$\mathrm{C} / \mathrm{N}$ values do not show significant differences among the nine physiographic regions (ANOVA Kruskal-Wallis: $\left.\mathrm{H}=7.27, \mathrm{p}=0.50 ; \chi^{2}=5.87, \mathrm{p}=0.66\right)($ Figure 10$) . \mathrm{C} / \mathrm{N}$ is low in the Campeche continental slope and Campeche Knolls $(\mathrm{C} / \mathrm{N}=7.6 \pm 1.1, \mathrm{n}=11)$, followed by the continental slope of the western Gulf of Mexico $(\mathrm{C} / \mathrm{N}=7.8 \pm 1.5, \mathrm{n}=$ 22). The highest values are recorded in the continental rise of the SW Gulf of Mexico $(\mathrm{C} / \mathrm{N}=8.4 \pm 1.1, \mathrm{n}=12)$ and in the Campeche Canyon $(\mathrm{C} / \mathrm{N}=8.3 \pm 1.8, \mathrm{n}=10)$. Significant differences occur between the Veracruz continental slope stations and the continental rise in the SW Gulf of Mexico (U Mann-Whitney: $\left.Z_{(-2.02)}=-2.02 ; \mathrm{p}=0.04\right)$, the western Gulf of Mexico continental slope $\left(Z_{(1.67)}=1.67 ; p=0.09\right)$ and the Campeche Canyon $\left(Z_{(-1.85)}=1.85 ; p=0.06\right)$, as well as between the SW Gulf of Mexico continental rise and the Campeche Knolls (U Mann-Whitney: $Z_{(-1.7)}=-1.7 ; p=0.08$ ).

\subsubsection{Inter-yearly C/N ratio variability: the Sigsbee abyssal plain permanent long term ecological research station}

The highest $\mathrm{C} / \mathrm{N}$ was recorded in 2002 (10.3), the lowest in 2005 (6.6), and a diminishing trend in $\mathrm{C} / \mathrm{N}$ is recorded with time (Figure 6). These differences adjust to a linear distribution (Spearman: $\mathrm{R}=1, \mathrm{p}=0.01, \mathrm{r}^{2}=0.91$, explaining 
TOC (\%)

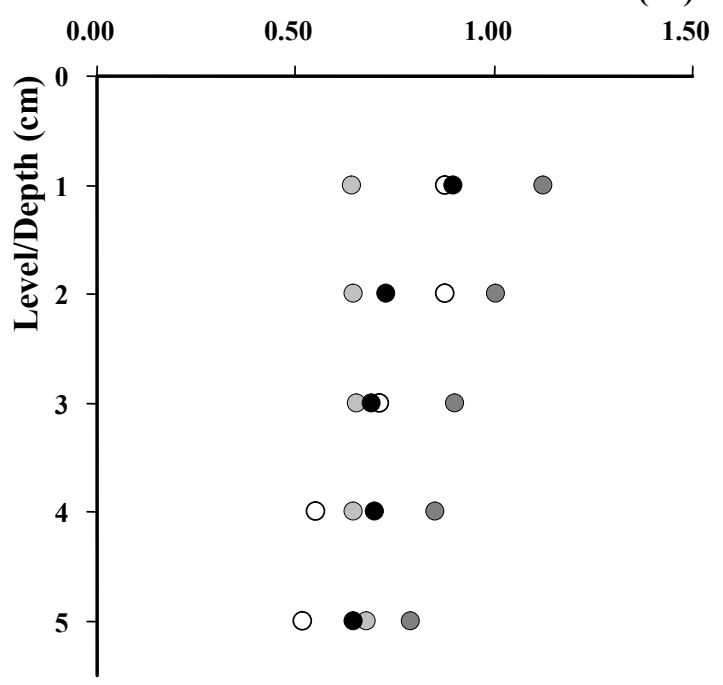

$\mathbf{C} / \mathbf{N}$

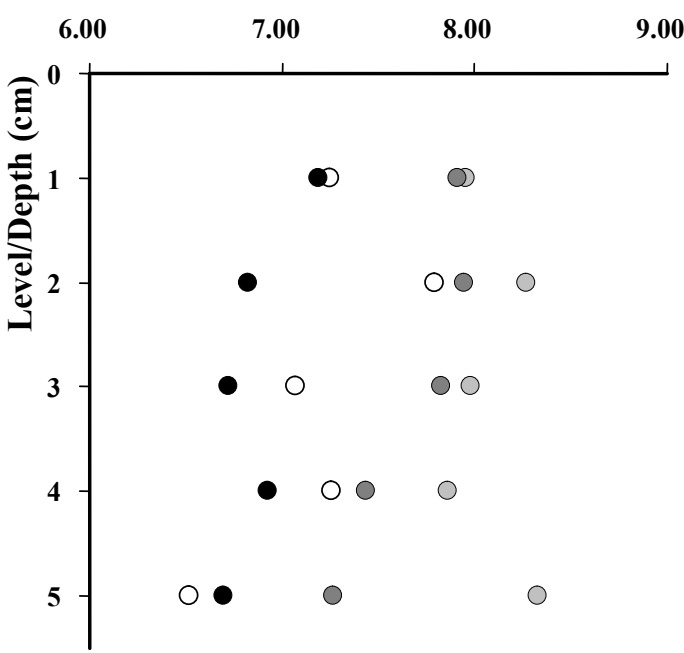

Figure 7. Sediment TOC, TN and C/N variability caused by the sedimentation conditions. Station locations shown above.

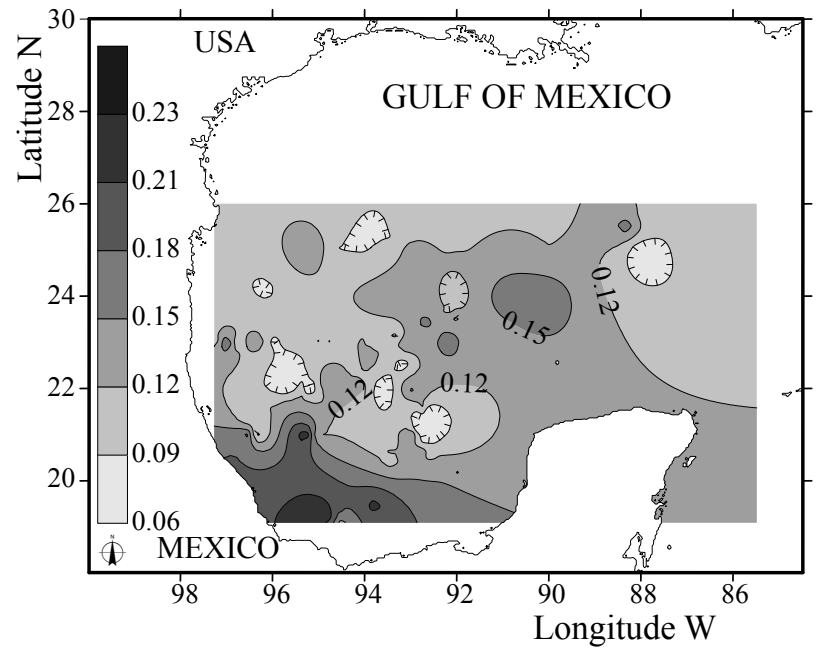

Figure 8. Sediment TN concentration isopleths in the southwestern Gulf of Mexico. Values in percentage.
O E1 $3344 \mathrm{~m}$

O E3 3166m

- E5 3495m

- E8 3526m
TN (\%)

0.00

0.05

0.10 0.15 


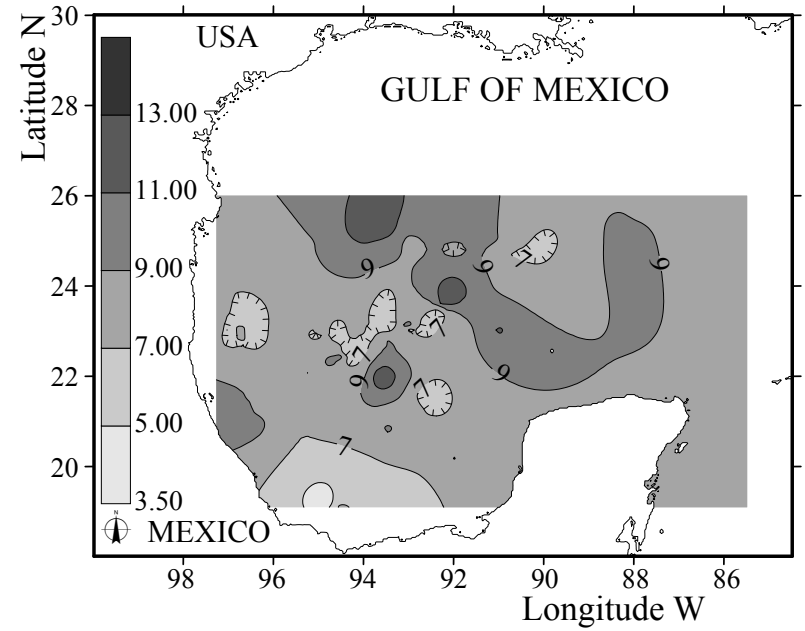

Figure 10. Sediment $\mathrm{C} / \mathrm{N}$ isopleths in the southwestern Gulf of Mexico.

$91 \%$ of the values).

\subsection{5. $C / N$ variability in response to the sedimentation conditions}

$\mathrm{C} / \mathrm{N}$ decreases with depth within the sediment column in only one (E5, cruise SIGSBEE.8) of the four sampling stations (Spearman: $\mathrm{R}=0.8862, \mathrm{p}<0.05$ ) (Figure 7).

\section{Discussion}

\subsection{Variability of the sediment elemental composition}

The expected TOC values for deep-sea sediments that characterize low export (Suess, 1980) under well oxygenated conditions (Stein, 1990) are $<0.5 \%$ (Seiter et al., 2004). The mean values recorded in this study are slightly higher than expected $(0.9 \pm 0.3 \%$, range $0.26-1.80 \%, \mathrm{n}=$ $115)$, but are lower than those recorded in the continental margins ( $>1.5 \%$ in Seiter et al., 2004; $4-16 \%$ in Arthur et al., 1998) and cold seas $(0.5-2 \%$; Stein, 1990, 1991). The TOC values are similar to those recorded for the northern Gulf of Mexico (0.34-1.59\% in Goñi et al., 1997, 1998; Gordon and Goñi, 2004; 0.37-1.3\% in Morse and Beazley, 2008) and those from other basins at similar latitudes, i.e.: the Argentina Basin (0.26-1.72\% in Stevenson and Cheng, 1972), and the Arabian Sea (0.04-1.5\% in Grandel et al., 2000). The highest value in this study is in agreement with the values described by Seiter et al. (2004) for tropical regions, including the continental margin of western Africa.

The $\mathrm{TN}$ values span over a wider range $(\mathrm{TN}=0.04$ $0.25 \%, 0.12 \pm 0.03 \%, \mathrm{n}=115$ ) than those expected for northern sector of the Gulf of Mexico (TN $=0.08-0.17 \%$ in Goñi et al., 1998; Gordon and Goñi, 2004). This variability is explained by the broader geographical coverage of this study. The obtained TN values are similar to those from the Argentina Basin $(\mathrm{TN}=0.031-0.167 \%$ in Stevenson and Cheng, 1972), are lower than those recorded in the continental margin of the Arabian Sea (0.1-0.4\% in Suthhof et al., 2000), and higher than those recorded in the China Sea (0.02-0.19\% in Kao et al., 2003).

Nitrogen in deep-sea sediments is mostly organic (Hedges et al., 1988). The inorganic fraction recognized in our samples, in view of the intercept in the TOC vs. TN lineal correlation (Figure 9), can be explained by ammonium trapped in the clay fraction (Stevenson and Cheng, 1972) that usually occurs in the sediment at depths greater than 1,000 m (Meyers, 1994).

The organic material of photoautotrophic origin mixes with continental organic matter near the coast and is usually transported by turbidity currents to the abyssal plain (Suthhof et al., 2000; Mari et al., 2001; Epping et al., 2002; Gordon and Goñi, 2004). Values of carbon-nitrogen atomic ratio $\left(\mathrm{C} / \mathrm{N}_{\mathrm{a}}\right)>15$ suggest an organic matter input derived from vascular plants (Meyers, 1994), characterized by limiting nitrate concentration (Mari et al., 2001). The mean value in our study $(\mathrm{C} / \mathrm{N}=8.0 \pm 1.7$, equivalent to $\left.\mathrm{C} / \mathrm{N}_{\mathrm{a}}=9.3\right)$ is above the Redfield ratio $\left(\mathrm{C} / \mathrm{N}=5.7, \mathrm{C} / \mathrm{N}_{\mathrm{a}}=\right.$ 6.65; Gordon and Goñi, 2004; Weston and Joye, 2005). Such a data range lies within the $\mathrm{C} / \mathrm{N}_{\mathrm{a}}$ of algae $\left(\mathrm{C} / \mathrm{N}_{\mathrm{a}}=4-10\right.$ in Meyers, 1994) and of recently settled detrital organic matter $\left(\mathrm{C} / \mathrm{N}_{\mathrm{a}} \approx 8\right.$ in Tahey et al., 1994). The lowest values in this study $\left(\mathrm{C} / \mathrm{N}_{\mathrm{a}}<5\right)$ are within the recorded range of open-ocean deep-sea sediments (Fütterer, 2000). The TN of the deep-sea sediments avoids being remineralized into the water column by adsorption to the mineral clay surface, hence recording smaller C/Natios (Stevenson and Cheng, 1972; Suthhof et al., 2000) that are explained by selective degradation of the organic compounds, and by immobilization of $\mathrm{N}$ by microorganisms during early diagenesis (Meyers, 1994).

The largest $\mathrm{C} / \mathrm{N}_{\mathrm{a}}$ ratios recorded in this study are similar to those recorded off the Mississippi delta (10-13 in Gordon and Goñi, 2004) and other basins at similar depths.

Other factors that can indicate the origin of organic matter in the sediments, but not performed in this study, include the Hydrogen index, microscopic observations, and carbon stable isotopic composition (Stein, 1990, 1991). The stable isotope composition of particulated organic matter in deep seawater samples from the same stations in the Gulf of Mexico $\left(\delta^{13} \mathrm{C}-25.3\right.$ to $-22.70 \%$ in the abyssal plain, and $\delta^{13} \mathrm{C}-24.11$ to $-22.12 \%$ in the continental slope) indicate a photoautotrophic origin, with depleted values caused by the time of residence in the water column with a contribution of suspended material from the sediment (González-Ocampo, 2005; González-Ocampo et al., 2007).

The local primary productivity, the preservation rate, and the input of continental organic matter are mechanisms that control the flux of organic matter in the sediment (Stein, 1991). The absence of a correlation of the TOC with depth in our study differs from the pattern previously recorded in the northern sector of the Gulf of Mexico (Morse and 
Beazley, 2008), in several regions of the world ocean (Suess, 1980 ) and in TN in the global seafloor (Fütterer, 2000). Our results can be herein interpreted to be a consequence of bathymetric features (Mexican ridges, abyssal knolls) in the W and SW Gulf. These would have caused differences in the continental input and sediment transport, with minimum remineralization rates of organic matter recorded at 1,000$2,000 \mathrm{~m}$ and increasing in the abyssal plain. A similar gradual increase was recorded at 2,000-3,750 $\mathrm{m}$ by Morse and Beazley (2008) in the northern Gulf, decreasing with depth, in a similar way as the quartz-free fraction described by Müller and Suess (1979) in offshore sediments.

The increase of TN with depth has been previously recorded as a consequence of the adsorption to clay minerals that protects the organic fraction from remineralization (Stevenson and Cheng, 1972; Suthhof et al., 2000). The organic matter follows the same distribution pattern of clay in the Gulf of Mexico (Balsam and Beeson, 2003). A similar distribution pattern in TOC and TN has been recorded in the Arctic (Stein, 1990, 1991) and in the Arabian Sea (Suthhof et al., 2000). Bioturbation plays an important role in the remineralization of particulate organic carbon (POC) that arrives to the seafloor (Emerson et al., 1985), affecting the TOC distribution, as recorded in the Mediterranean Sea (Tahey et al., 1994) and in regions with laminated sediments characterized by hypoxic conditions and better organic matter preservation (Suthhof et al., 2000).

$\mathrm{C} / \mathrm{N}$ increases in the world ocean with depth $\left(\mathrm{C} / \mathrm{N}_{\mathrm{a}} 8\right.$ to 10 in Honjo et al., 1982). The sigmoidal pattern recorded in this study suggests a common origin, controlled by the sedimentation rate and by the preservation along the depth gradient, as reported in other regions (Suthhof et al., 2000).

\subsection{Variability with distance from the coast}

In marginal seas, the coastal effect on the deep sea is large and is recorded by the terrigenous organic matter input (Cranston, 1997). The presence of continental material in the central part of the basin suggests a long lateral transport (Stevenson and Cheng, 1972; Cranston, 1997) from the Mississippi River (Bouma, 1972; Balsam and Beeson, 2003) and from turbidity currents that are due to the hurricane effect on the slope (Stevenson and Cheng, 1972). The differences recorded between sectors from the northern and western Gulf of Mexico can be attributed, as in other sites, to local faunal activity in the sediments (Stevenson and Cheng, 1972).

\subsection{Variability by physiographic regions}

The elemental composition and distribution in the sediments can provide information on the deposit, current patterns and primary productivity conditions (Stein, 1990, 1991). The elemental composition in the Gulf of Mexico deep sediments follows a distribution similar to the phytoplankton biomass obtained with satellite images, with local differences attributed to continental inputs (Balsam and Beeson, 2003).

The inexistent N-S and E-W differences in the Gulf of Mexico, besides those given by sand and carbonates, suggest a homogeneous basin (Balsam and Beeson, 2003). The transition between terrigenous and carbonate provinces has been suggested along the $75 \% \mathrm{CaCO}_{3}$ isobaths (HernándezArana et al., 2005). A correlation between organic matter and $\mathrm{CaCO}_{3}$ has been described in the water column (Suess, 1970) and in the sediment-water interface, for both TOC (Suess, 1973) and TN (Müller and Suess, 1977). The N-S differences can be attributed to the effect of the Mississippi River (McKee et al., 2004) reaching the abyssal plain (Bouma, 1972; Balsam and Beeson, 2003) that has been recorded in superficial sediments (Goñi et al., 1997, 1998; Gordon and Goñi, 2004), similar to this study.

The lowest $\mathrm{C} / \mathrm{N}$ in the southern Gulf is related to the pelagic origin of organic matter in the Campeche Bay, with eutrophic and mesotrophic conditions associated to the Grijalva-Usumacinta front (Signoret et al., 2006) that differs from values in the central Gulf of Mexico. In spite of its regional relevance and continental input to the basin (Carranza-Edwards et al., 1993), its effect is significantly minor, with $\mathrm{C} / \mathrm{N}_{\mathrm{a}}=9.2$, in contrast to the $\mathrm{C} / \mathrm{N}_{\mathrm{a}}=13.8$ at the same depth range in the northern sector. In addition, the $\mathrm{C} / \mathrm{N}$ associated to asphalt seeps is significantly higher than in the surrounding abyssal sediments (50 vs. 7 ), thus providing evidence of local high hydrocarbon input (MacDonald et al., 2004; Canet et al., 2006). Seeps from the northern sector have high TOC values $(>9.4 \%)$, with $\mathrm{C} / \mathrm{N}$ notably lower $(\approx 6.1)$ than neighboring sediments (Paull et al., 1992).

Local high TOC values in the Campeche Knolls area do not correlate with $\mathrm{TN}$ in presence of $\mathrm{S}(\mathrm{S}=1.9 \pm 1.9 \%, \mathrm{n}=$ 23). This suggests high sulfur reduction rates (Arvidson $e t$ al., 2004) and chemosynthetic activity (MacDonald et al., 2004), and indicates inorganic N predominance, absent in the typical abyssal soft sediments in the region.

\subsection{Inter-yearly TN variability: the Sigsbee abyssal plain permanent station}

Tropical deep-sea ecosystems receive low input of photoautotrophic organic matter through time (Jahnke, 1996; Cosson et al., 1997). The Gulf of Mexico flux to the deep seafloor is controlled by different time scale effects (Wiseman and Sturges, 1999): (1) upwelling associated to the Loop Current and the gyres (Biggs and MüllerKarger, 1994; Lohrenz et al, 1994), (2) the Mississippi and Atchafalaya river input in the northern sector (Wiseman and Sturges, 1999), and (3) the Grijalva-Usumacinta river input in the southwestern sector (Signoret et al., 2006) contribute with nutrients and localized fluxes of particles to the deep sea. Upwelling varies at a monthly scale (Biggs and Müller-Karger, 1994) whereas river input presents a yearly variability (Wiseman and Sturges, 1999). The pulses of organic matter to the seafloor respond to two time scales, 
short and long term, that result in a geographic mosaic (Aller, 1997). The long-term ecological research station of the central abyssal plain is affected by the yearly flux. The decrease in $\mathrm{C} / \mathrm{N}_{\mathrm{a}}$ from 12.0 (in 2002) to 7.7 (in 2005) in the abyssal plain reflects a mixture of continental organic matter from the Mississippi through turbidity currents (Bouma, 1972; Bryant et al., 1991) and gravity fluxes (Normark et al., 1993; Morse and Beazley, 2008) with predominantly pelagic materials exported in 2002 (Gordon and Goñi, 2004). A similar pattern was recorded by Rabiela-Alonso (2006) in macrofaunal density values that can be linked to the $\mathrm{C} / \mathrm{N}$ ratios of this study by bioturbation and remineralization. $E l$ Niño years contribute with organic matter export to the deep sea in the Gulf of Mexico (Escobar-Briones, 2003) and, as recorded in other basins, may generate inter-yearly changes in the flux to the seafloor (Smith and Druffel, 1998).

\subsection{Variability in response to the sedimentation conditions}

TOC and TN decrease with depth in the sediments, while $\mathrm{C} / \mathrm{N}$ increases by remineralization by microorganisms and metazoans in a well-oxygenated seafloor (Canfield, 1994; Wakeham, 2002). The pattern recorded in three sediment cores can be explained by such a mechanism. The core collected in the Mississippi Fan follows the characteristics described by Stevenson and Cheng (1972) and Grandel et al. (2000) for turbiditic sediments and lacks the typical pattern recorded in other cores from the area (Normak et al., 1993; Morse and Beazley, 2008).

\section{Conclusions}

TOC and TN concentrations in the southwestern Gulf of Mexico are in agreement with deep-sea values, and $\mathrm{N}$ is predominantly organic. The highest values are associated to hydrocarbon seepage in the abyssal plain. The polynomial distribution trends of TOC and TN with depth, and the C/N homogeneity in three depth intervals suggest an input of continental organic matter that was transported offshore.

This study shows significant differences among depth intervals and physiographic regions of the southwestern Gulf of Mexico. Variability was recorded in the long-term station and can be interpreted as inter-yearly differences in the export of POC to the seafloor related to hydrodynamic and climatic events in the region. Variability was also recorded in sediment cores from the abyssal plain, thus indicating lateral transport from the Mississippi Fan to the abyssal plain.

\section{Acknowledgments}

Valuable reviews to an earlier version were provided by Drs. L. E. Vera (School of Chemistry UNAM), M.
L. Machain (ICML), C. Mortera (I. Geophysics), and P. Blanchon (ICML-PM). The elemental analysis was performed by Ms N. López Balbiux, USAI. The crews of R/V Justo Sierra and Gyre supported the fieldwork. PAPIIT IN 204307, IN224503 and SEP-CONACyT 40158 grants financially supported the development of this project. MMS financed the DGoMB project leaded by G.T. Rowe, TAMUG.

\section{References}

Aller, J.Y., 1997, Benthic community response to temporal and spatial gradients in physical disturbance within a deep-sea western boundary region: Deep-Sea Research I, 44, 39-69.

Aller, R.C., Mackin J.E., 1984, Preservation of reactive organic matter in marine sediments: Earth and Planetary Sciences Letters, 70, 260-266.

Arthur, M.A., Dean, W.E., Laarkamp, K., 1998, Organic carbon accumulation and preservation in surface sediments on the Peru margin: Chemical Geology, 152, 273-286.

Arvidson, R.S., Morse, J.W., Joye, S.B., 2004, The sulfur biogeochemistry of chemosynthetic cold seep communities, Gulf of Mexico, USA: Marine Chemistry, 87, 97-119.

Balsam, W.L., Beeson, J.P., 2003, Sea-floor sediment distribution in the Gulf of Mexico: Deep-Sea Research I, 50, 1421-1444.

Biggs, D.C., Müller-Karger, F.E., 1994, Ship and satellite observations of chlorophyll stocks in interacting cyclone-anticyclone eddy pairs in the western Gulf of Mexico: Journal of Geophysical Research, 99(C4), 7371-7384.

Bordovskiy, O.K., 1965a, Accumulation of organic matter in bottom sediments: Marine Geology 3, 33-82.

Bordovskiy, O.K., 1965b, Transformation of organic matter in bottom sediments and its early diagenesis: Marine Geology, 3, 83-114.

Bouma, A.H., 1972, Distribution of sediments and sedimentary structures in the Gulf of Mexico, in Rezak, R., Henry, V.J. (eds.), Contribution on the geological and geophysical oceanography of the Gulf of Mexico: Texas A\&M University Oceanography Studies 3, 35-65.

Bryant, W.R., Lugo, J., Córdova, C., Salvador, A., 1991, Physiography and bathymetry, in Salvador, A. (ed.), The Gulf of Mexico Basin: Boulder, Colorado, Geological Society of America, The Geology of North America, 13-30.

Canet, C., Prol-Ledesma, R.M., Escobar-Briones, E., Mortera-Gutiérrez, C., Lozano-Santa Cruz, R., Linares, C., Cienfuegos, E., MoralesPuente, P., 2006, Mineralogical and geochemical characterization of hydrocarbon seep sediments from the Gulf of Mexico: Marine and Petroleum Geology, 23, 605-619.

Canfield, D.E., 1994, Factors influencing organic carbon preservation in marine sediments: Chemical Geology, 114, 315-329.

Carranza-Edwards, A., Rosales-Hoz, L., Monreal-Gómez, A., 1993, Suspended sediments in the southeastern Gulf of Mexico: Marine Geology, 112, 257-269.

Coleman, J.M., Roberts, H.H., Bryant, W. R., 1991, Late Quaternary sedimentation, in Salvador, A. (ed.), The Gulf of Mexico Basin: Boulder, Colorado, Geological Society of America, The Geology of North America, 325-352.

Cosson, N., Sibuet, M., Galeron, J., 1997, Community structure and spatial heterogeneity of the deep-sea macrofauna at three contrasting stations in the tropical northeast Atlantic: Deep-Sea Research I, 44, 247-269.

Cranston, R.E., 1997, Organic carbon burial rates across the Arctic Ocean from the 1994 Arctic Ocean Section expedition: Deep-Sea Research II, 44, 1705-1723.

Cwienk, D.S., 1986, Recent and glacial age organic carbon and biogenic silica accumulation in marine sediments: University of Rhode Island, MSc dissertation, $237 \mathrm{p}$.

Emerson, S., Fischer, K., Reimers, C., Heggie, D., 1985, Organic carbon dynamics and preservation in deep-sea sediments: Deep-Sea 
Research, 32, 1-21.

Epping, E., van der Zee, C., Soetaert, K., Helder, W., 2002, On the oxidation and burial of organic carbon in sediments of the Iberian margin and Nazaré Canyon (NE Atlantic): Progress in Oceanography, 52, 399-431.

Escobar-Briones, E., 2003, The effect of the 1997-1998 ENSO on the benthic macrofaunal biomass in the southern Gulf of Mexico: Geofísica Internacional, 42, 517-522.

Fütterer, D.K., 2000, The solic phase of marine sediments, in Schulz, H.D., Zabel, M., (eds.), Marine Geochemistry: Berlin, Springer, 1-26.

González-Ocampo, M., Escobar-Briones, E. Morales, P., 2007, Composición y caracterización isotópica $\delta^{13} \mathrm{C}$ de carbono orgánico particulado en aguas oceánicas del sureste del Golfo de México, in: Gaxiola Castro, G., \& B. Hernández de la Torre (Comp), Carbono en ecosistemas acuáticos de México: INE-CICESE, 75- 100.

González-Ocampo, M., 2005, Composición y caracterización isotópica $\delta^{13} \mathrm{C}$ de partículas de carbono orgánico en estratos batimétricos de aguas oceánicas del suroeste del Golfo de México: Universidad Nacional Autónoma de México, MSc dissertation, 76 p.

Goñi, M.A., Ruttenberg, K.C., Eglinton, T.I., 1997, Sources and contribution of terrigenous organic carbon to surface sediments in the Gulf of Mexico: Nature, 389, 275-278.

Goñi, M.A., Ruttenberg, K.C., Eglinton, T.I., 1998, A reassessment of the sources and importance of land-derived organic matter in surface sediments from the Gulf of Mexico: Geochimica et Cosmochimica Acta, 62, 3055- 3075 .

Gordon, E.S., Goñi, M.A., 2004, Controls on the distribution and accumulation of terrigenous organic matter in sediments from the Mississippi and Atchafalaya river margin: Marine Chemistry, 92, 331-352.

Grandel, S., Rickert, D., Schlüter, M., Wallmann, K., 2000, Pore-water distribution and quantification of diffusive benthic fluxes of silicic acid, nitrate and phosphate in surface sediments of the deep Arabian Sea: Deep-Sea Research II, 47, 2707-2734.

Hedges, J.I., Clark, W.A., Cowie, G.L., 1988, Organic matter sources to the water column and surficial sediments of marine bay: Limnology and Oceanography, 33, 1116-1136.

Hedges, J.I., Keil, R.G., 1995, Sedimentary organic matter preservation: an assessment and speculative synthesis: Marine Chemistry, 49, 81-115.

Hernández-Arana, H.A., Attrill, M.J., Hartley, R., Gold-Bouchot, G., 2005, Transitional carbonate-terrigenous shelf sub-environments inferred from textural characteristics of surficial sediments in the Southern Gulf of Mexico: Continental Shelf Research, 25, 1836-1852.

Honjo, S., Manganini, S.J., Cole, J.J., 1982, Sedimentation of biogenic matter in the deep ocean: Deep-Sea Research, 29, 609-625.

Jahnke, R.A., 1996, The global ocean flux of particulate organic carbon: areal distribution and magnitude: Global Biogeochemical Cycles, $10,71-88$

Kao, S.J., Lin, F.J., Liu, K.K., 2003, Organic carbon and nitrogen contents and their isotopic compositions in surficial sediments from the East China Sea shelf and the southern Okinawa Trough: Deep-Sea Research II, 50, 1203-1217.

Lee, C., 1994, Controls on carbon preservation - New perspectives: Chemical Geology, 114, 285-288.

Lohrenz, S.E., Fahnenstiel, G.L., Redalje D.G., 1994, Spatial and temporal variations of photosynthetic parameters in relation to environmental conditions in coastal waters of the northern Gulf of Mexico: Estuaries, 17, 779-795.

Lohrenz, S.E, Wiesenburg, D.A, Arnone, R.A, Chen, X., 1999, What controls primary production in the Gulf of Mexico?, in Kumpf, H., Steidinger, K., Sherman, K., (eds.), The Gulf of Mexico large marine ecosystem: Maiden, MA, Blackwell Science, 151-170.

MacDonald, I.R., Bohrmann, G., Escobar, E., Abegg, F., Blanchon, P., Blinova, V., Brückmann, W., Drews, M., Eisenhauer, A., Han, X., Heeschen, K., Meier, F., Mortera, C., Naehr, T., Orcutt, B., Bernard, B., Brooks, J., de Faragó, M., 2004, Asphalt volcanism and chemosynthetic life in the Campeche Knolls, Gulf of Mexico: Science, 304, 999-1002.

Mari, X., Beauvais, S., Lemée, R., Pedroti, M.L., 2001, Non-Redfield
C:N ratio of transparent exopolymeric particles in the northwestern Mediterranean Sea: Limnology and Oceanography, 46, 1831-1836.

Mayer, L.M., 1993, Organic matter at the sediment-water interface, in Engel, M.H., Macko, S.A., (eds), Organic Geochemistry - principles and applications: New York, Plenum Press, 171-184.

McKee, B.A., Aller, R.C., Allison, M.A., Bianchi, T. S., Kineke, G.C., 2004, Transport and transformation of dissolved and particulate materials on continental margins influenced by major rivers: benthic boundary layer and seabed processes: Continental Shelf Research, 24, 899-926.

Meyers, P.A., 1994, Preservation of elemental and isotopic source identification of sedimentary organic matter: Chemical Geology, 114, 289-302.

Mollenhauer, G., Schneider, R.R, Müller, P.J., 2002, Glacial/interglacial variability in the Benguela upwelling system: spatial distribution and budgets of organic carbon accumulation: Global Biogeochemical Cycles, 16, 1134, doi:10.1029/2001GB001488.

Monreal-Gómez, M.A., Salas de León, D.A., 1997, Circulación y estructura termohalina del Golfo de México, in Lavin, M.F. (ed), Contribuciones a la oceanografía física de México: Unión Geofísica Mexicana, Monografía 3, 183-199.

Morse, J.W., Beazley, M.J., 2008, Organic matter in deepwater sediments of the Northern Gulf of Mexico and its relationship to the distribution of benthic organisms: Deep-Sea Research II, 55, 2563-2571.

Müller, P.J., Suess, E., 1977, Interaction of organic compounds with calcium carbonate - III. Amino acid composition of sorbed layers: Geochimica et Cosmochimica Acta, 41, 941-949.

Müller, P.J., Suess, E., 1979, Productivity, sedimentation rate and sedimentary organic matter in the oceans - I. Organic carbon preservation: Deep-Sea Research, 26A, 1347-1362.

Normark, W.R., Posamentier, H., Mutti, E., 1993, Turbidite systems - state of the art and future directions: Reviews of Geophysics, 31, 91-116.

Paull, C.K., Chanton, J.P., Neumann, A.C., Coston, J.A., Martens, C.S., Showers, W., 1992, Indicators of methane-derived carbonates and chemosynthetic organic carbon deposits - examples from the Florida Escarpment: Palaios, 7, 361-375.

Pequegnat, W.E., 1970, Deep-water brachyuran crabs, in Pequegnat, W.E., Chace, F.A. Jr. (eds.), Contributions on the biology of the Gulf of Mexico: Texas A\&M University Oceanography Studies, 171-204.

Premuzic, E.T., Benkovitz, C.M., Gaffney, J.S., Walsh, J.J., 1982, The nature and distribution of organic matter in the surface sediments of world oceans and seas: Organic Geochemistry, 4, 63-77.

Rabiela-Alonso, D., 2006, Variación espacio - temporal de la densidad de la macrofauna béntica de la planicie abisal en el Golfo de México: Facultad de Ciencias, Universidad Nacional Autónoma de México, bachelor's thesis, $52 \mathrm{p}$.

Roberts, H.H., McBride, R.A., Coleman, J.M., 1999, Outer shelf and slope geology of the Gulf of Mexico - An Overview, in Kumpf, H, Steidinger, K., Sherman, K., (eds.), The Gulf of Mexico large marine ecosystem: Maiden, MA, Blackwell Science, 93-112.

Seiter, K., Hensen, C., Schröter J., Zabel, M., 2004, Organic carbon in surface sediments - defining regional provinces: Deep-Sea Research I, 51, 2001-2026.

Shiller, A.M. 1999, An Overview of the marine chemistry of the Gulf of Mexico, in Kumpf, H, Steidinger, K., Sherman, K., (eds.), The Gulf of Mexico large marine ecosystem: Maiden, MA, Blackwell Science, 132-148.

Signoret, M., Monreal-Gómez, M.A., Aldeco, J., Salas de León, D.A., 2006, Hydrography, oxygen saturation, suspended particulate matter and chlorophyll-a fluorescence in an oceanic region under freshwater influence: Estuarine, Coastal and Shelf Science, 69, 153-164.

Smith, K.L., Jr., Druffel, E.R.M., 1998, Long time - series monitoring of an abyssal site in the NE Pacific: an introduction: Deep-Sea Research II, 45, 573-586.

Stein, R., 1990, Organic carbon content/sedimentation rate relationship and its paleoenviromental significance for marine sediments: GeoMarine Letters, 10, 37-44.

Stein, R., 1991, Accumulation of organic carbon in marine sediments: Berlin, Springer-Verlag, $217 \mathrm{p}$. 
Stevenson, F.J., Cheng, C.-N., 1972, Organic geochemistry of the Argentine Basin sediments - carbon-nitrogen relationships and Quaternary correlations: Geochimica et Cosmochimica Acta, 36, 653-671.

Suess, E., 1970, Interaction of organic compounds with calcium carbonate - I. Association phenomena and geochemical implications Geochimica et Cosmochimica Acta, 34, 157-168.

Suess, E., 1973, Interaction of organic compounds with calcium carbonate - II. Organo-carbonate association in Recent sediments: Geochimica et Cosmochimica Acta, 37, 2435-2447.

Suess, E., 1980, Particulate organic carbon flux in the oceans - surface productivity and oxygen utilization: Nature, 288, 260-263

Suthhof, A., Jennerjahn, T.C., Schäfer, P., Ittekkot, V., 2000, Nature of organic matter in surface sediments from the Pakistan continental margin and the deep Arabian Sea - amino acids: Deep-Sea Research II, 47, 329-351.

Tahey, T.M., Duineveld, G.C.A., Berghuis, E.M., Helder, W., 1994 Relation between sediment-water fluxes of oxygen and silicate and faunal abundance at continental shelf, slope and deep-water stations in the northwest Mediterranean: Marine Ecology Progress Series, 104, 119-130.

Vetrov, A.A., Romankevitch, E.A., 1997, New charts of distributions of organic carbon and coefficients of its fossilization in the bottom sediments of the ocean: Oceanology of the Russian Academy of Sciences, 37, 769-775

Vetrov, A.A., Romankevitch, E.A., Benenson, M.A., 1997, Computer compilation of organic carbon distribution maps for bottom sediments: Oceanology of the Russian Academy of Sciences, 37, 651-656.
Wakeham, S., 2002, Diagenesis of organic matter at the water-sediment interface, in Gianguzza, A., Pelizzetti, E., Sammartano, S. (eds.), Chemistry of marine water and sediments: Berlin, Springer 147-164.

Weston, N.B., Joye, S.B., 2005, Temperature-driven decoupling of key phases of organic matter degradation in marine sediments: PNAS, 102, 17036-17040.

Wiseman, W.J., Jr., Sturges W., 1999, Physical Oceanography of the Gulf of Mexico: Processes that Regulate its Biology, in Kumpf, H., Steidinger, K., Sherman, K. (eds.), The Gulf of Mexico large marine ecosystem: Maiden, MA, Blackwell Science, 77-92.

Wollast, R., 1998, Evaluation and comparison of the global carbon cycle in the coastal zone and in the open ocean, in Brink, K.H., Robinson, A.R. (eds.), The Sea -The Global Coastal Ocean: New York, John Wiley \& Sons, 213-252.

Zabel, M., Dahmke, A., Schulz, H.D., 1998, Regional distribution of diffusive phosphate and silicate fluxes through the sediment-water interface - the eastern South Atlantic: Deep-Sea Research I, 45, $277-300$.

Manuscript received: July 28, 2008.

Corrected manuscript received: November 20, 2008.

Manuscript accepted: December 20, 2008. 